\title{
Radiotherapy in Malignant Myoepithelioma of the Soft Palate - Case Report
}

\author{
Renata Soumarováa Zuzana Lovasováa Marie Vaňkováa $^{a}$ \\ Ladislav Sokol ${ }^{b}$ \\ aDepartment of Oncology and Radiotherapy and ${ }^{\mathrm{b}}$ Department of Pathology, \\ Mendel Cancer Center, Nový Jičín, Czech Republic
}

\section{Key Words}

Malignant myoepithelioma $\cdot$ Soft palate $\cdot$ Radiotherapy

\begin{abstract}
Myoepithelioma is a very rare neoplasm that accounts only for about $1 \%$ of all salivary gland tumours. As the lesion is so rare, there are no specific recommendations or guidelines for its treatment. In the literature, there have been only a few cases reported without any existing data concerning radiotherapy. We present a very good palliative effect of radiotherapy in a very old man.
\end{abstract}

\section{Introduction}

Myoepitheliomas are rare tumours that account for about $1 \%$ of all salivary gland tumors [1]. Most of them are benign, while some are malignant.

Most of them occur in the parotid gland (40\%); few other sites in the head and neck region have been reported in the literature; for example in the oral cavity, palate, retromolar area, cheek, or larynx [2-4]. Sheldon was the first who used the term myoepithelioma in 1943, and in 1975 Stromeyer et al. reported the first case of malignant myoepithelioma (MM) [5, 6]. MM are classified into 4 cell types: epithelioid, spindle, clear, and plasmacytoid. Of these, the plasmacytoid cell type appears to have a predilection for the oral cavity, especially the palate $[7,8]$. The myoepithelioma cells are usually positive for cytokeratins, especially for CK7 and CK14, and reactive for smooth muscle actin, S100 protein, muscle-specific actin (MSA), and smooth muscle myosin heavy chain (SMM) [9] (ig. 1). MM may occur within pre-existing benign lesions like pleomorphic adenomas or benign myoepitheliomas, but it may also occur de novo [10]. Myoepitheliomas usually present as slow-growing painless masses.

Renata Soumarová, MD, Ass. Prof., Mendel Cancer Center, Purkyňova 2138/16 


\begin{tabular}{|c|c|c|c|}
\hline $\begin{array}{l}\text { Cose Reports in } \\
\text { Cincilosy }\end{array}$ & $\begin{array}{l}\text { Case Rep Oncol 2009;2:116-120 } \\
\text { Dol: } 10.1159 / 000228546\end{array}$ & Published online: July 17, 2009 & $\begin{array}{l}\text { (c) } 2009 \text { S. Karger AG, Basel } \\
\text { ISSN } 1662-6575 \\
\text { www.karger.com/cro }\end{array}$ \\
\hline
\end{tabular}

As the lesion is so rare, there no specific guidelines have been introduced for its treatment. The primary treatment is mostly surgical.

\section{Case Report}

A 90-year-old white man presented with an exophytic, bleeding, ovoid swelling at the right side of the soft palate growing up for 1.5 years. Physical examination found the exophytic, slightly bleeding tumour with intact skin (fig. 2). The deformation and pathological tissue (average $4.5 \mathrm{~cm}$ ) involving the soft palate were shown by CT scan. An excisional biopsy that proved the malignant myoepithelioma was performed. The diagnosis was then verified by a second pathological review, which confirmed the plasmocytoid myoepithelioma with the typical immunoprofile: positive CK 7, CK14, S100, MSA and SMM.

The criteria confirming the malignancy of myoepithelial neoplasms include their destructive infiltrating growth, cellular pleomorphism, necrosis, and an increased mitotic activity.

Surgery is a gold standard treatment option in this type of tumour, but considering the age and performance status of our patient, we gave preference to radiotherapy (RT) with palliative intent. We intended to apply the dose above $60 \mathrm{~Gy}$ and therefore selected the intensity modulate technique of RT (fig. 3). The total dose of 62.5 Gy was administered in 25 fractions with respect to the tumour characteristic and in quest of shortening treatment time. The toleration of this treatment was very good. Acute toxicity according to RTOG criteria included hypogeusia, slight dysphagia and mucositis grade 1. The radiotherapy was completed according to our plan. Three months after finishing RT we observed a good response; the tumour decreased in volume and the bleeding was stopped. Another regression of tumour was achieved after 6 months. The volume had decreased progressively to $2 \mathrm{~cm}$ in diameter. 18 months after the treatment, only a very small residuum of tumour was shown (fig. 4 ). The very excellent palliative effect sustained for 2.5 years after RT. Late toxicity of the treatment was minimal, the patient complained only of slight dryness of his mouth (grade 1).

\section{Discussion}

Malignant myoepithelioma is a very rare disease, and for that reason no standard primary and/or adjuvant treatment has been established. The treatment of choice is radical surgery. Nevertheless, this strategy was not possible in our patient with respect to his age and performance status. Sporadic cases of this disease (only 20 within the recent 25 years) were published in the English written medical literature, mainly dealing with its cytological and immunohistological complexities [11-13]. Only some papers mentioned surgical treatment and its extent, particularly in the head and neck region $[14,15]$.

$\mathrm{RT}$ is often a curative modality in the treatment of solid tumours. Additionally, it is indicated as a palliative treatment, aimed predominantly at decreasing the signs and symptoms and to prolong disease-free survival. Particularly in tumours originated in the head and neck region, the planning of high-dosed RT is very complicated. The irradiation of radiosensitive structures can cause very unpleasant symptoms, including mucositis, pain, injury to the salivary glands, etc. Therefore, we used a modern technique of RT - the intensity-modulated technique. Its advantages are a better adjustment of the dose distribution, the possibility to apply a high dose, and a lesser volume of irradiation to the healthy tissue.

Up to now, the use of RT in this type of tumour has not been known. Now we can take the introduction of RT into account in the management of this type of tumours, mainly in cases that are not suitable for surgery. 


\begin{tabular}{c|l|l|l}
$\begin{array}{c}\text { Cose Reports in } \\
\text { Ondobogy }\end{array}$ & $\begin{array}{l}\text { Case Rep Oncol 2009;2:116-120 } \\
\text { Dol: 10.1159/000228546 }\end{array}$ & & $\begin{array}{l}\text { P 2009 S. Karger AG, Basel } \\
\text { ISSN 1662-6575 } \\
\text { www.karger.com/cro }\end{array}$ \\
\hline
\end{tabular}

\section{Conclusion}

We report the first use of the RT in malignant myoepithelioma with very excellent palliative effect and local control. RT may possibly have a curative effect in some cases and it could become an alternative modality in very old or severely ill patients.

Fig. 1. SMA positive myoepithelial cells in malignant myoepithelioma (SMA, $\times 400)$.

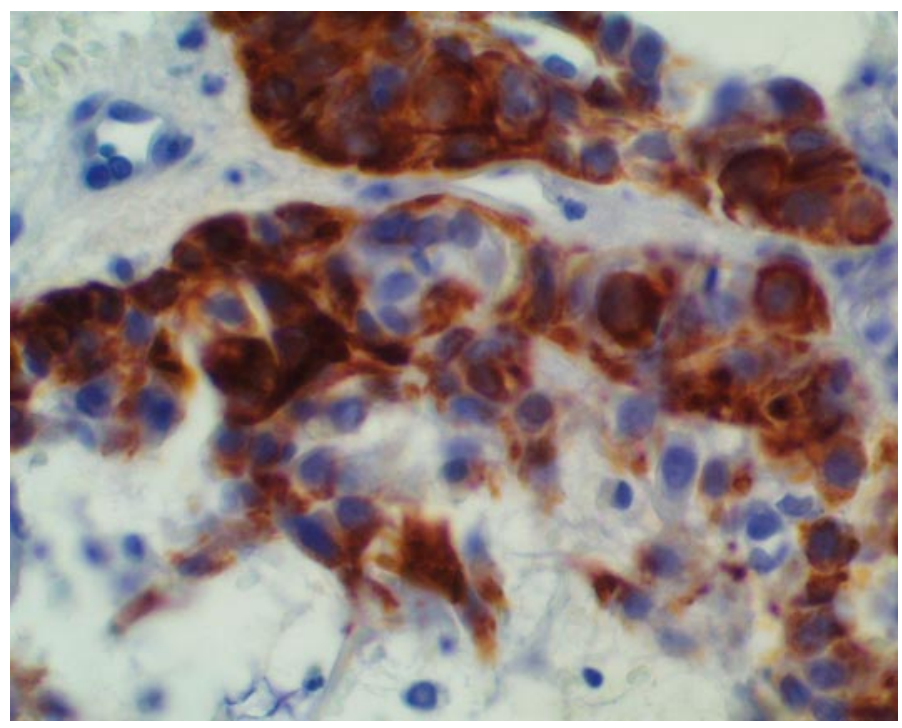

Fig. 2. An exophytic, bleeding, ovoid swelling at the right side of the soft palate in a 90 -year-old man.

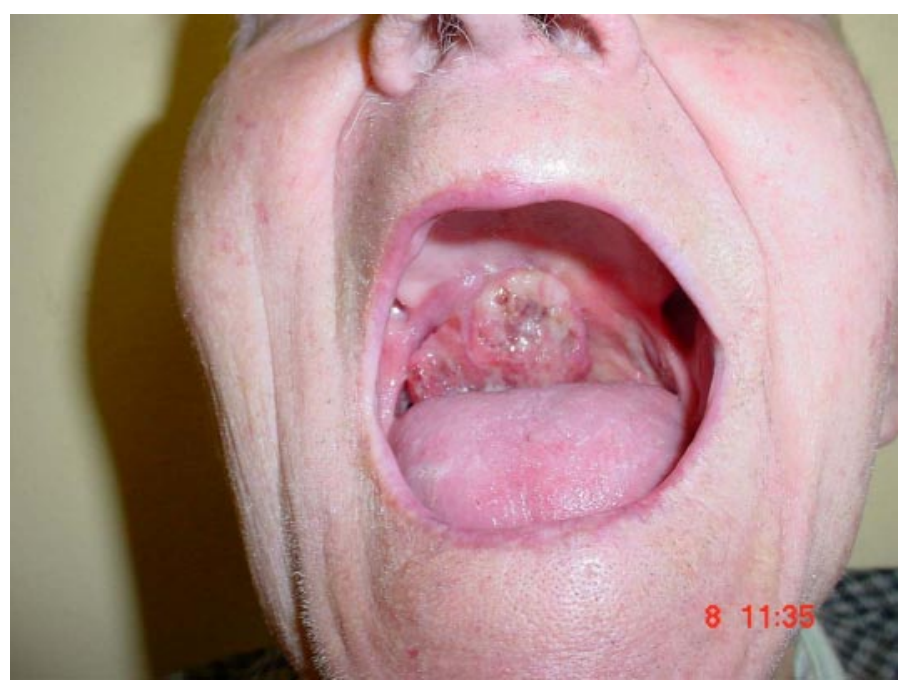




\begin{tabular}{c|l|l|l}
$\begin{array}{c}\text { Cose Reports in } \\
\text { Oncolady }\end{array}$ & $\begin{array}{l}\text { Case Rep Oncol 2009;2:116-120 } \\
\text { D0I: 10.1159/000228546 }\end{array}$ & Published online: July 17, 2009 & $\begin{array}{l}\text { O 2009 S. Karger AG, Basel } \\
\text { ISSN 1662-6575 } \\
\text { www.karger.com/cro }\end{array}$ \\
\hline
\end{tabular}

Fig. 3. Technique of intensity-modulated radiotherapy: red line = planning target volume; colour area $=$ dose of $62.5 \mathrm{~Gy}$ (100\% of prescribed dose).

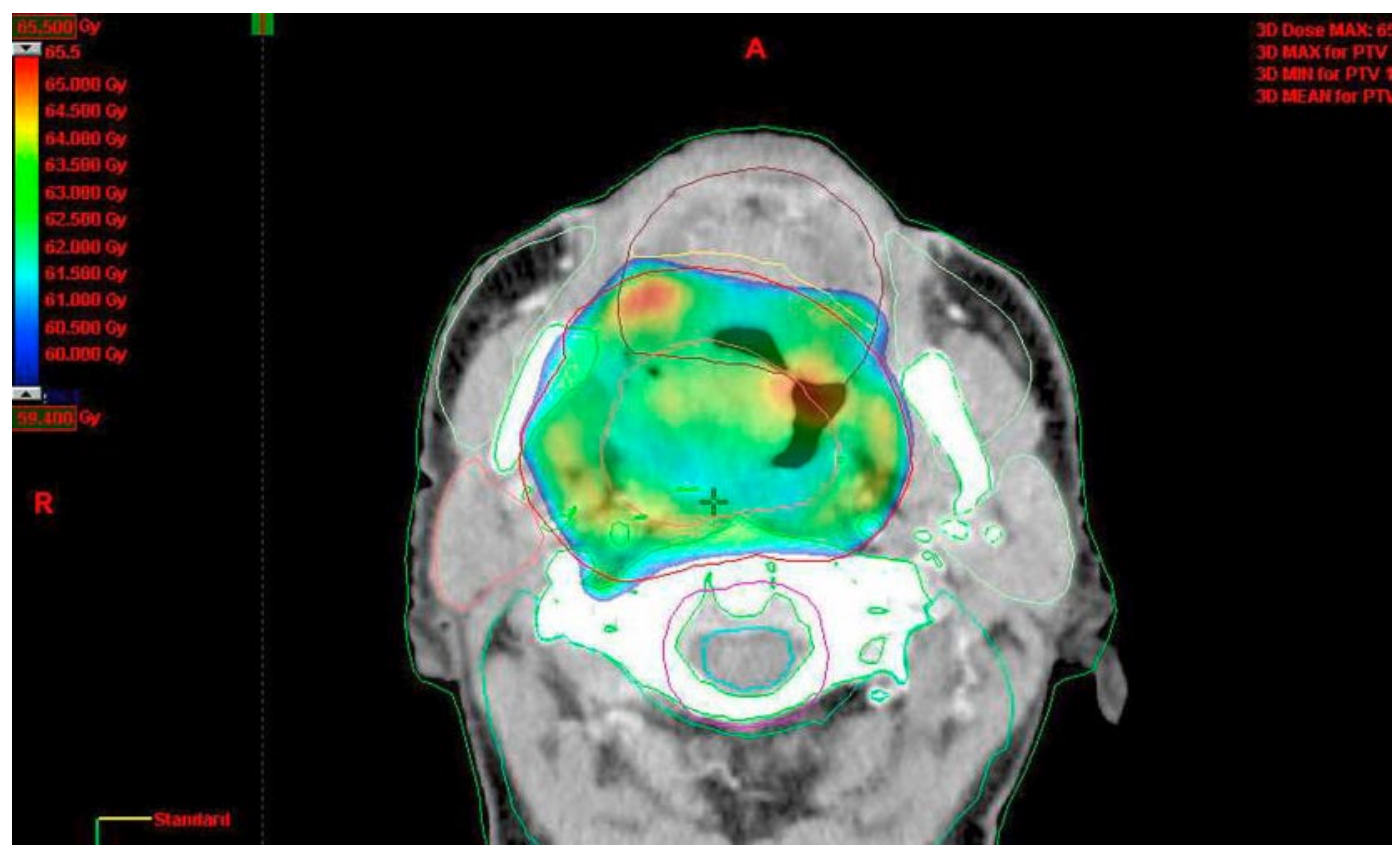

Fig. 4. 18 months after finishing radiotherapy: only a small residual tumour on the right side of the palate.

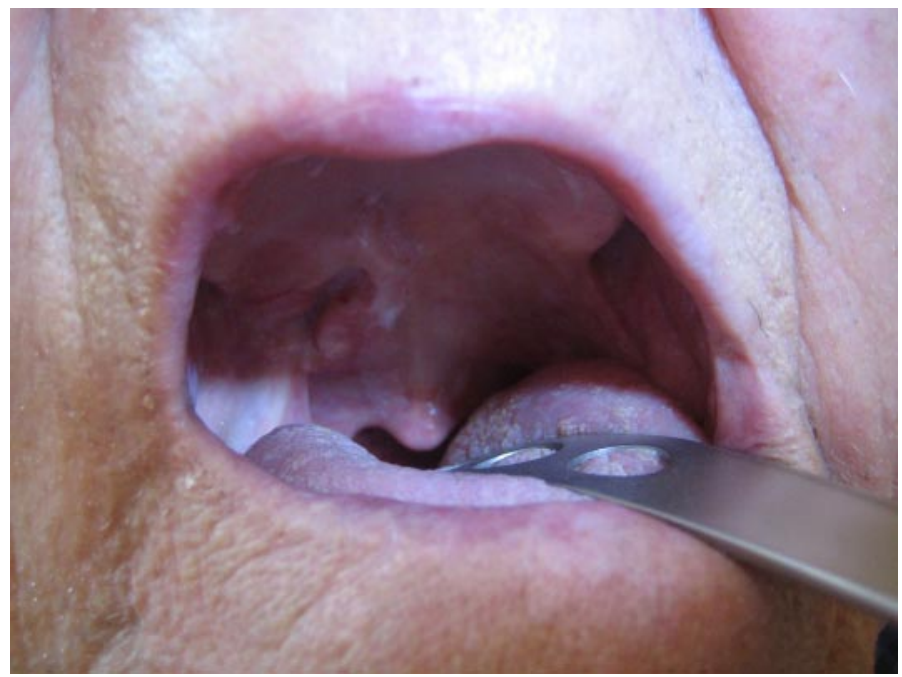




\section{References}

1 Sciubba JJ, Brannon RB: Myoepithelioma of salivary glands: report of 23 cases. Cancer 1982;49:562-572.

2 Sayed SI, Kazi RA, Jagade MV, Palav RS, Shinde VV, Pawar PV: A rare myoepithelioma of the sinonasal cavity: case report. Cases J 2008;1:29.

3 Magliulo G, Pulice G, Fusconi M, Cuiuli G: Malignant myoepithelioma of the rhinopharynx: case report. Skull Base 2005;15:113-116; discussion 117.

4 Testa D, Galera F, Insabato L, Vassallo A, Mesolella M, Galli V: Submandibular gland myoepithelioma. Acta Otolaryngol 2005;125:664-666.

5 Sheldon WH: So-called mixed tumours of the salivary glands. Arch Pathol 1943;35:1-20.

6 Stromeyer FW, Haggitt RC, Nelson JF, Hardman JM: Myoepithelioma of minor salivary gland origin. Arch Pathol 1975;99:242-245.

7 Cuadra Zelaya F, Quezada Rivera D, Tapia Vazquez JL, Paez Valencia C, Gaitán Cepeda LA: Plasmacytoid myoepithelioma of the palate. Report of one case and review of the literature. Med Oral Patol Oral Cir Bucal 2007;12:E552-E555.

8 Bakshi J, Parida PK, Mahesha V, Radotra BD: Plasmacytoid myoepithelioma of palate: three rare cases and literature review. J Laryngol Otol 2007;121:e13.

9 Açikalin MF, Paşaoğlu O, Cakli H, Ciftçi E: Plasmacytoid myoepithelioma of the soft palate: a review of the literature and report of a case with immunohistochemical findings. Indian J Pathol Microbiol 2004;47:236-237.

10 Young J, Barker M, Robertson T, et al: A case of myoepithelial carcinoma displaying biallelic inactivation of the tumour suppressor gene APC in a patient with familial adenomatous polyposis. J Clin Pathol 2002;55:230-232.

11 López JI, Ugalde A, Arostegui J, Bilbao FJ: Plasmacytoid myoepithelioma of the soft palate. Report of a case with cytologic, immunohistochemical and electron microscopic studies. Acta Cytol 2000;44:647-652.

12 Kuwabara H, Uda H, Miyabe K, Saito K, Shibanushi T: Malignant plasmacytoid myoepithelioma of the palate: histological observations compared to benign predominant plasmacytoid myoepithelial cells in pleomorphic adenoma of the palate. Ultrastruct Pathol 1998;22:153-160.

13 Chhieng DC, Paulino AF: Cytology of myoepithelial carcinoma of the salivary gland. Cancer 2002;96:32-36.

14 Barnes L, Appel BN, Perez H, El-Attar AM: Myoepithelioma of the head and neck: case report and review. J Surg Oncol 1985;28:21-28.

15 Nayak JV, Molina JT, Smith JC, et al: Myoepithelial neoplasia of the submandibular gland: case report and therapeutic considerations. Arch Otolaryngol Head Neck Surg 2003;129:359-362. 